\title{
Exercise-induced asthma without respiratory heat loss
}

\author{
ISSAHAR BEN-DOV, EPHRAIM BAR-YISHAY, SIMON GODFREY
}

\begin{abstract}
From the Pulmonary Function Laboratory and Department of Pediatrics, Hadassah University Hospital, Jerusalem, Israel
\end{abstract}

It is well documented that exercise-induced asthma is more pronounced when inspired air is cold and dry rather than warm and humid. ${ }^{2}$ The severity of exercise-induced asthma is closely dependent on loss of respiratory heat, needed to warm and humidify inspired air, ${ }^{3}$ and it has been suggested that airway cooling is the only stimulus triggering postexercise bronchoconstriction. ${ }^{3-7}$ We present a case of an asthmatic patient who has repeatedly developed exercise-induced asthma while breathing air at body temperature and humidity with no respiratory heat loss.

\section{Case report}

The patient is a 13-year-old asthmatic boy with a known history of bronchial asthma and hay fever for the last nine years. He was referred to us after his mother had observed him suffering multiple episodes of wheezing and shortness of breath resulting from normal playground activities. Subsequently he has been treated successfully with beclomethasone dipropionate aerosol for his perennial asthma and with salbutamol aerosol for his exercise-induced asthma. During his investigation a series of exercise tests were performed to learn about his exercise tolerance under various air conditions.

The patient came to the laboratory after refraining from taking any drugs for at least 12 hours before the visit. He performed a forced vital capacity manoeuvre to determine his baseline lung function. He then started breathing warm humidified air supplied to him from a thermally insulated circuit through a low-resistance one-way valve. Warm humidified air was obtained by the use of a conventional nebuliser heater (Ohio Medical Products). The temperature of the air measured at the inspiratory port of the mouthpiece was $37 \cdot 1^{\circ} \mathrm{C}$ fully saturated (water content 44.2 $\mathrm{mg}$ per litre of air). There were free water drops throughout all the tubing.

After he had breathed the gas for 10 minutes, forced vital capacity manoeuvres were repeated and the patient then proceeded to perform a standard six-minute exercise test on a cycle ergometer (Lode Instruments) while continuously breathing the warm humidified gas. During the exercise test expired air was passed through a mixing chamber and pneumotachygraph system coupled with gas analysers and a microprocessor (PK Morgan Exercise Test System). This enabled us to monitor ventilation and gas exchange every half minute.

Address for reprint requests: Dr S Godfrey, Department of Pediatrics, Hadassah University Hospital, Mount Scopus, Jerusalem, Israel.
Lung function was measured at intervals after the end of $\underset{\hat{x}}{\vec{x}}$ exercise without alteration of the inspired gas by means of $w$ a Fleisch No 3 pneumotachygraph and an integrator $\infty$ (47804A Pulmonary Calculator System, Hewlett Packard). The subject made two or three attempts at forced $\mathcal{C}^{\circ}$ vital capacity manoeuvres each time and the best forced 0 expired volume in one second $\left(\mathrm{FEV}_{1}\right)$ was chosen. All measurements were performed while the patient was sea- $D$ ted on the cycle ergometer. The severity of exerciseinduced asthma was calculated as the maximum percentage fall of FEV 1 after exercise:

$\Delta \mathrm{FEV}_{1}(\%)=\left(1-\frac{\text { minimum postexercise } \mathrm{FEV}_{1}}{\text { pre-exercise } \mathrm{FEV}_{1}}\right) \times 100$

where the pre-exercise value was that measured immedi- $\bar{\partial}$ ately before starting exercise while the boy was breathing

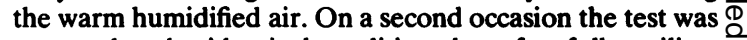
repeated under identical conditions but after full sterilisation of the equipment. On a third occasion the test was repeated while the patient was breathing cold, dry air which was supplied to him by passing compressed air through calcium chloride and a simple refrigeration unit. All tests were performed on separate days over an eightday period.

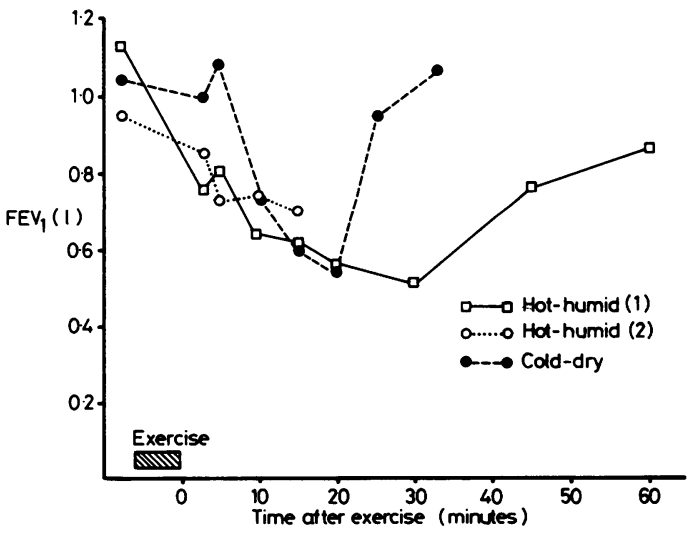

$F E V$, before and at intervals after a six-minute cycling exercise under different respired air conditions: hot, humid air test (1)-control; repeat hot, humid air test (2) after sterilisation of respiratory test system; cold, dry air test. 
Values of pre-exercise $F E V_{1}$ and exercise respiratory parameters for the three tests

\begin{tabular}{|c|c|c|c|}
\hline & $\begin{array}{l}\text { Warm humid } \\
\text { air } \\
\text { test } 1\end{array}$ & $\begin{array}{l}\text { Warm humid } \\
\text { air } \\
\text { test } 2\end{array}$ & $\begin{array}{l}\text { Cold dry } \\
\text { air } \\
\text { test }\end{array}$ \\
\hline $\begin{array}{l}\text { Pre-exercise } \mathrm{FEV}_{\mathbf{1}}(\mathrm{l}) \\
\text { Minute ventilation }(\mathrm{l} / \mathrm{min}) \\
\text { Heart rate (beats/min) }\end{array}$ & $\begin{array}{l}1 \cdot 13 \\
42 \cdot 0 \\
158\end{array}$ & $\begin{array}{l}0 \cdot 95 \\
40 \cdot 8 \\
162\end{array}$ & $\begin{array}{c}1 \cdot 04 \\
42 \cdot 0 \\
159\end{array}$ \\
\hline $\begin{array}{l}\text { Oxygen consumption } \\
(\mathrm{ml} / \mathrm{min})\end{array}$ & 1318 & 1294 & 1258 \\
\hline
\end{tabular}

In the first test, during the breathing of warm humid air, the baseline $\mathrm{FEV}_{1}$ was $53 \%$ of predicted normal. ${ }^{8}$ Average minute ventilation, heart rate, and oxygen consumption over the last three minutes of exercise were $421 / \mathrm{min}, 158$ beats $/ \mathrm{min}$, and $1318 \mathrm{ml} / \mathrm{min}$ respectively, the oxygenconsumption being $60 \%$ of predicted maximum. ${ }^{9}$ The mean expired air temperature was $37 \cdot 3^{\circ} \mathrm{C}$, compared with $37 \cdot 1^{\circ} \mathrm{C}$ for the inspired gas, and thus the respiratory heat loss was negligible. The maximum fall in $\mathrm{FEV}_{1}$ was $55 \%$. The changes in lung function are shown in the figure. The second test was identical to the first in all respects and the response was very similar, as the figure shows. Measurement of lung function was stopped 15 minutes after the end of exercise when FEV, was still falling and the patient was given a bronchodilator. This was done because he showed severe shortness of breath coupled with signs of nausea. He was tested for the third time while breathing cold and dry air $\left(5 \cdot 7^{\circ} \mathrm{C}\right.$, water content $2.05 \mathrm{mg} \mathrm{H}_{2} \mathrm{O} / 1$ air). With the exception of the inspired air conditions, this third test was identical to the first two. He again developed exercise-induced asthma similar to that which he had developed previously in the two tests with warm humidified air, as shown in the figure, the maximum fall in FEV, being $47 \%$.

\section{Discussion}

We report the case of a 13-year-old boy with bronchial asthma who consistently developed exercise-induced asthma while breathing warm and humid air at body temperature and humidity. This observation is contrary to previous reports, ${ }^{1-4}$ which have attributed exercise-induced asthma to airway cooling, since in our case respiratory heat loss was negligible. To exclude the possibility that the attack was caused by an immunological rather than a mechanical stimulus the whole system was fully sterilised before we undertook the repeat test. Before sterilisation multiple cultures showed a growth of mixed cocci and Alternaria spp, but after sterilisation only cocci were cultured. The patient was tested for skin sensitivity to Alternaria but did not react. As a final check on the possibility that asthma was caused by the apparatus, the patient breathed the same total volume of gas at the same temperature and humidity at rest as he had during his exercise tests. No detectable bronchoconstriction occurred.

We believe this to be the first case in which a patient was not protected by the warm humidified environment during exercise and developed as severe exercise-induced asthma as during exercise while breathing cold dry air. Possibly his response was related to his relatively low baseline level of $\mathrm{FEV}_{1}$ - most subjects reported previously have had more normal baselines. The protective effect of warm humid air might thus have been somewhat exaggerated by testing relatively fit patients.

\section{References}

' Bar-Or O, Neuman I, Dotan R. Effects of dry and humid climate on exercise-induced asthma in children and pre-adolescents. $J$ Allergy Clin Immunol 1977;60:163-8.

${ }^{2}$ Chen WY, Horton DJ. Heat and water loss from the airways and exercise-induced asthma. Respiration 1977;34:305-13

${ }^{3}$ Deal EC Jr, McFadden ER Jr, Ingram RH Jr, Strauss RH, Jaeger $\mathrm{JJ}$. Role of respiratory heat exchange in production of exercise-induced asthma. J Appl Physiol: Respir Environ Exercise Physiol 1979; 46:467-75.

4 Deal EC Jr, McFadden ER Jr, Ingram RH Jr, Jaeger JJ. Hyperpnea and heat flux: initial reaction sequence in exercise-induced asthma. J Appl Physiol: Respir Environ Exercise Physiol 1979;46:476-83.

${ }^{5}$ Resnick AD, Deal EC Jr, Ingram RH Jr, McFadden ER Jr. A critical assessment of the mechanism by which hyperoxia attenuates EIA. J Clin Invest 1979;64:541-9.

${ }^{6}$ Zeballos RJ, Sturman-Elstein R, McNally JF Jr, Hirsch JE, Souhrada $\mathrm{J}$. The role of hyperventilation in exercise induced bronchoconstriction. Am Rev Respir Dis 1978;118:877-84.

${ }^{7}$ Ocain CF, Dowling NB, Slutsky AS, Hensley MJ, Strohl KP, McFadden ER Jr, Ingram RH Jr. Airways effects of respiratory heat loss in normal subjects. J Appl Physiol: Respir Environ Exercise Physiol 1980;49:875-80.

- Polar G, Promadhat V. Pulmonary function testing in children: techniques and standards. Philadelphia: WB Saunders, 1971.

${ }^{9}$ Godfrey S. Exercise testing in children. London: WB Saunders, 1974. 